\title{
PENGARUH SENAM DIABETES TERHADAP KADAR GULA DARAH PADA PASIEN DIABETES MELLITUS TIPE 2 DI WILAYAH PUSKESMAS PERIUK JAYA KOTA TANGERANG
}

\author{
EFFECT OF DIABETIC GYMNASTICS ON BLOOD SUGAR LEVELS IN \\ PATIENTS WITH DIABETES MELLITUS TYPE 2 IN THE AREA OF \\ HEALTH CENTERS PERIUK JAYA TANGERANG
}

\author{
Wasludin, Lindawati* \\ Poltekkes Kemenkes Banten \\ Korespondensi: wasludin@poltekkesbanten.ac.id
}

\begin{abstract}
In the management of diabetes mellitus, there are 4 kinds of education, food planning, and DM Pharmaceuticals. Regular exercise for DM treatment programs, especially type II DM benefits will be more effective when the type of exercise performed the majority using large muscles of the body, with rhythmic movements (rhythmically) and Continuous (continuous) for a long time. Based on preliminary studies, in the area of work Puskesmas Periuk Jaya Tangerang City has not been conducted non-pharmacological action especially exercise (diabetic gymnastics) and there has been no research on that, so the author is interested to do research titled "The Effect of diabetic gymnastics on blood sugar levels in Diabetes mellitus patient type 2 at Puskesmas Periuk Jaya Kota Tangerang Year 2018".

The purpose of this research is to know the influence of diabetic gymnastics in maintaining blood sugar levels in Diabetes mellitus type 2 patients, with experimental quasi design with the approach to re-experimental draft (pre-test-post Test group design), in the subject of test/measurement before and after treatment.

The results of the study were being there was a significant difference in the average of the guladdirection between before and after the intervention of either the intervention with the gymnastics and the intervention with no gymnastics in the same. Because the characteristic homogeneity of the respondent is not fulfilled, other researchers should conduct research using better sampling methods and techniques to get better results again.
\end{abstract}

Keywords : Diabetes Mellitus, Blood Sugar, Tend Gymnastics

\begin{abstract}
ABSTRAK
Pengelolalan diabetes melitus ada 4 macam yaitu edukasi, perencanaan makanan, olahraga, dan obat-obatan DM. Olahraga teratur untuk program pengobatan DM, terutama DM tipe II manfaatnya akan lebih efektif bila jenis olahraga yang dilakukan mayoritas menggunakan otototot besar tubuh, dengan gerakan-gerakan ritmis (berirama) dan berkesinambungan (kontinyu) dalam waktu yang lama.

Berdasarkan studi pendahuluan, diwilayah kerja Puskesmas Periuk Jaya Kota Tangerang belum dilakukan tindakan secara non farmakologis khususnya olah raga (senam diabetes) dan belum ada penelitian tentang itu, sehingga penulis tertarik untuk melakukan penelitian berjudul
\end{abstract}


"Pengaruh Senam Diabetes terhadap kadar gula darah pada pasien Diabetes Melitus type 2 di Puskesmas Periuk Jaya Kota Tangerang Tahun 2018”.

Tujuan penelitian ini ingin mengetahui pengaruh Senam Diabetes dalam mempertahankan kadar gula darah pada pasien Diabetes Melitus type 2, dengan desain penelitian quasi eksperimental dengan pendekatan rancangan eksperimental ulang (pre test-post test group design), yaitu pada subjek dilakukan test/pengukuran sebelum dan sesudah perlakukan.

Hasil penelitian, diperoeh ada perbedaan yang signifikan rata-rata guladarah sewaktu antara sebelum dan setelah intervensi baik yang intervensi dengan senam diabet maupun intervensi dengan bukan senam diabet. Karena homogenitas karakteristik responden tidak terpenuhi, maka disarankan kepada peneliti lain agar melakukan penelitian dengan menggunakan metode dan teknik sampling yang lebih baik untuk mendapatkan hasil yang lebik baik lagi.

\section{Kata Kunci : Diabetes Melitus, Gula Darah, Senam Diabet}

\section{PENDAHULUAN}

Diabetes mellitus adalah gangguan metabolisme yang ditandai dengan hiperglikemi yang berhubungan dengan abnormalitas metabolisme karbohidrat, lemak dan protein yang disebabkan oleh penurunan sekresi insulin atau keduanya dan menyebabkan komplikasi kronis mikrovaskuler, makrovaskuler, dan neuropati, (Elin, 2009).

Berdasarkan hasil kunjungan di Puskesmas Periuk Jaya satu tahun terakhir dari Januari 2016 sampai Februari 2017 terdapat 491 penderita diabetes dengan kisaran usia 45-60 tahun keatas .

Menurut Santoso dalam Suryanto (2009), pengelolalan diabetes melitus ada 4 macam yaitu edukasi, perencanaan makanan, olahraga, dan obat-obatan DM (OHO, Insulin). Olahraga teratur untuk program pengobatan DM, terutama DM tipe II sudah dikenal sejak lama selain diet dan obatobatan.

Manfaat olahraga ditentukan oleh tipe penyakit diabetes. Pada DM tipe I peran olahraga yang teratur pada penurunan kadar gula darah masih kontroversial. Perbedaan DM tipe I dan DM tipe II adalah pada DM tipe I mempunyai kadar insulin darah yang rendah akibat kurang atau tidak adanya produksi insulin oleh pankreas. Pada DM tipe I mudah mengalami hipoglikemia selama dan segera sesudah berolahraga. Pada DM tipe II Olahraga berperan utama dalam pengaturan kadar gula darah, pada tipe ini produksi insulin umumnya tidak terganggu terutama pada awal menderita penyakit ini, selain bermanfaat dalam mengontrol kadar gula darah, olahraga pada DM tipe II diharapkan dapat menurunkan berat badan.

Berdasarkan studi pendahuluan berkaitan dengan penatalaksanaan diabetes diwilayah 
kerja Puskesmas Periuk Jaya Kota Tangerang belum secara rutin dilakukan tindakan secara non farmakologis khususnya olah raga (senam diabetes) dan belum ada penelitian tentang itu, sehingga penulis tertarik untuk melakukan penelitian berjudul "Pengaruh Senam Diabetes terhadap kadar gula darah pada pasien Diabetes Melitus di Wilayah Kerja Puskesmas Periuk Jaya Kota Tangerang Tahun 2018”.

Tujuan penelitian ini yaitu ingin mengetahui distribusi frekuensi penderita diabetes melitus yang melakukan olahraga senam diabetes, ingin mengetahui perbedaan kadar gula darah sebelum dan sesudah olahraga senam diabetes pada pasien Diabetes Melitus, dan ingin mengetahui perbedaan kadar gula darah pada kelompok yang tidak olahraga senam diabetes dan kelompok yang olahraga senam diabetes pada pasien Diabetes Melitus

\section{METODE}

Desain penelitian yang digunakan adalah quasi eksperimental dengan pendekatan rancangan eksperimental ulang (pre test-post test group design), yaitu subjek dibagi 2 kelompok yaitu kelompok dengan senam diabetes dan kelompok yang bukan senam diabetes. Pada masing-masing kelompok sebelum mendapatkan intervensi dilakukan pemeriksaan kadar gula darah sewaktu kemudian dilakukan intervensi dan sesudah perlakuan dilakukan pengukuran kadar gula darah kembali. Pada kelompok pertama mendapatkan intervensi senam diabetes (x1) dan pada kelompok kedua mendapatkan intervensi bukan senam (x0). Pada setiap kelompok dilakukan intervensi berupa sebanyak 3 kali dan masing-masing intervensi dilakukan selama 30 menit, sehingga desain penelitian ini dapat digambarkan seperti skema berikut.

Senam Diabetes $\quad$ : 01 ----- x1 ------ o 2

Bukan senam diabetes: o3------ x0 ------ o 4

Populasi target pada penelitian ini adalah penderita diabetes melitus di Kelurahan Periuk Kecamatan Periuk Kota Tangerang dengan sampel sebanyak 68 orang penderita yang dikelompokkan menjadi 2 kelompok. Kelompok pertama diberikan intervensi senam diabetes dan kelompok kedua dengan intervensi bukan senam diabetes.

Varibel penelitian ini terdiri dari variabel independen (bebas) yaitu olahraga senam diabetes dan variabel dependen (terikat) yaitu penurunan kadar gula darah sewaktu. Tempat penelitian dilakukan pada penderita diabetes melitus di Puskesmas Periuk Jaya Kecamatan Periuk Kota Tangerang pada bulan Nopember 2018.

Pengumpulan data dilakukan dengan mengukur kadar gula darah responden, baik 
sebelum maupun sesudah intervensi dengan menggunakan alat yang disiapkan peneliti. Sebelum intervensi, responden diperiksa gula darahnya kemudian intervensi (senam) selama 30 menit, setelah itu responden istirahat sekitar 15 menit kemudian diukur lagi gula darahnya. Ini dilakukan pada kelompok intervensi dengan senam diabetes dan pada kelompok bukan senam diabetes selama 3 hari berturut-turut.

Data yang diperoleh kemudian diolah dan dianalisis secara deskriptif untk menggambarkan kadar gula darah sewaktu dari responden dan analisi bivariat dengan uji $\mathrm{T}$ untuk melihat ada tidaknya perbedaan antara kelompok senam dengan kelompok bukan senam.

Penelitian ini melibatkan petugas puskesmas sebagai pembantu peneliti dan mahasiswa keperawatan sebagai pembantu peneliti dalam memantau responden, mengukur kadar gula darah, membantu entry data dan distribusi keperluan selama penelitian. Ethical clearence berupa ijin dari instansi terkait dan persetujuan setelah penjelasan "inform consen" dari calon responden menjadi responden dalam penelitian ini.

\section{HASIL DAN PEMBAHASAN}

Tabel 1

Distribusi responden berdasarkan umur dan lama menderita diabetes

\begin{tabular}{lcccc}
\hline \multirow{2}{*}{ Klpk } & Umur & \multicolumn{3}{c}{ Lama DM } \\
\cline { 2 - 5 } & $<52$ th & $\geq 52$ th & $<7$ th & $\geq 7$ th \\
\hline Senam & 19 & 15 & 20 & 14 \\
\hline $\begin{array}{l}\text { Bukan } \\
\text { senam }\end{array}$ & 13 & 21 & 14 & 20 \\
\hline
\end{tabular}

Berdasarkan tabel 1, menunjukkan bahwa umur responden kelompok senam hampir sama antara umur kurang 52 tahun dengan umur 52 tahun keatas, sedangkan pada kelompok bukan senam perbedaanya relatif jauh yaitu yang berumur kurang 52 tahun ada 13 dan 52 tahun ke atas ada 21 orang. Berdasarkan lama menderita DM, pada kelompok senam, yang menderita 7 tahun keatas terdapat 14 orang dan pada kelompok bukan senam ada 20 orang.

Tabel 2

Distribusi responden berdasarkan diet dan gula darah sewaktu

\begin{tabular}{lcccc}
\hline \multirow{2}{*}{ Klpk } & \multicolumn{2}{c}{ Diet DM } & \multicolumn{2}{c}{ GDS } \\
\cline { 2 - 5 } & Ya & Tidak & $<217$ & $\geq 217$ \\
\hline Senam & 22 & 12 & 20 & 14 \\
\hline $\begin{array}{l}\text { Bukan } \\
\text { senam }\end{array}$ & 17 & 17 & 19 & 15 \\
\hline
\end{tabular}

Pada tabel 2 menunjukkan bahwa responden kelompok senam ada 12 orang yang tidak diet dan pada kelompok bukan senam ada 17 orang, sedangkan berdasarkan kadar gula darahnya, pada kelompok senam terdapat 14 yang kadar gula darahnya 217 atau lebih dan kelompok buka senam ada15 responden

Tabel 3

Distribusi responden menurut GDS sebelum dan setelah intervensi senam

\begin{tabular}{lcccc}
\hline Gula darah & Mean & SD & P-value & N \\
\cline { 1 - 3 } Sebelum & 217,85 & 85,00 & 0,000 & 34 \\
\cline { 1 - 3 } Setelah & 197,58 & 63,38 & & 34 \\
\hline
\end{tabular}


Rata-rata guladarah sewaktu responden sebelum intervensi adalah 217,85 dengan standar deviasi 85,00, sedangkan rata-rata guladarah sewaktu setelah intervensi 197,58 dengan standar deviasi 63,38. Hasil uji statistik diperoleh nilai $\mathrm{p}=0.000$ berarti pada alpha 5\% ada perbedaan yang signifikan rata-rata guladarah sewaktu antara sebelum dan setelah intervensi.

Tabel 4

Distribusi responden menurut GDS sebelum dan setelah intervensi tidak senam

\begin{tabular}{lcccc}
\hline Gula darah & Mean & SD & P-value & N \\
\hline Sebelum & 294,66 & 87,89 & 0,000 & 34 \\
\cline { 1 - 3 } Setelah & 273,16 & 72,77 & & 34 \\
\hline
\end{tabular}

Rata-rata guladarah sewaktu responden sebelum intervensi bukan senam adalah 294,66 dengan standar deviasi 87,89, sedangkan rata-rata guladarah sewaktu setelah intervensi bukan senam 273,16 dengan standar deviasi 72,77. Hasil uji statistik diperoleh nilai $\mathrm{p}=0.000$ berarti pada alpha $5 \%$ ada perbedaan yang signifikan rata-rata guladarah sewaktu antara sebelum dan setelah intervensi bukan senam.

Hasil uji statistik pada kelompok intervensi senam, diperoeh $p=0.000$ berarti pada alpha $5 \%$ ada perbedaan yang signifikan rata-rata guladarah sewaktu antara sebelum dan setelah intervensi, demikian juga pada kelompok intervensi bukan senam, hasil uji statistik diperoleh nilai $\mathrm{p}=0.000$ berarti pada alpha $5 \%$ ada perbedaan yang signifikan rata-rata guladarah sewaktu antara sebelum dan setelah intervensi bukan senam.

Latihan sangat penting dalam penatalaksanaan diabetes karena efeknya dapat menurunkan kadar glukosa darah dan mengurangi resiko kardiovaskuler. Latihan akan menurunkan kadar glukosa darah dengan meningkatkan pengambilan glukosa oleh otot dan memperbaiki pemakaian insulin. Sirkulasi darah dan tonus otot juga diperbaiki dengan berolahraga.Penderita diabetes harus diajarkan untukselalu melakukan latihan pada saat yang sama (sebaiknya ketika kadar glukosa darah mencapai puncaknya) dan intensitas yang sama setiap harinya. Latihan yang dilakukan setiap hari secara teratur lebih dianjurkan daripada latihan sporadik.

Senam diabetes dibuat oleh tim ahli yang terdiri atas tiga dokter (spesialis rehabilitasi medis, spesialis penyakit dalam, spesialis olahraga kesehatan), ahli gizi dan pelatih sanggar senam. Senam diabetes merupakan senam aerobic low impact dan ritmis dengan gerakan menyenangkan, tidak membosankan dan dapat diikuti semua kelompok umur sehingga menarik antusiasme kelompok dalam klub-klub diabetes. Senam diabetes 
merupakan gerakan senam yang penekanannya pada gerakan ritmik otot, sendi, vaskular dan saraf dalam bentuk peregangan dan relaksasi. Konsep gerakan pada senam sehat diabetes mellitus menggunakan konsep latihan ketahanan jantung paru (endurance) dengan mempertahankan keseimbangan otot kanan dan kiri.

Manfaat olahraga pada diabetisi antara lain meningkatkan penurunan kadar glukosa darah, mencegah kegemukan, ikut berperan dalam mengatasi kemungkinan terjadinya komplikasi aterogenik, gangguan lipid darah, peningkatan tekanan darah, hiperkoagulasi darah. Keadaan-keadaan ini mengurangi risiko penyakit jantung coroner (PJK) dan meningkatkan kualitas hidup diabetes dengan meningkatnya kemampuan kerja dan juga memberikan keuntungan secara psikologis.

Hasil ini sesuai dengan hasil penelitian Yendi dan Adwiyana (2014) tentang pengaruh latihan jasmani senam diabetes mellitus terhadap penurunan kadar gula darah penderita diabetes mellitus di wilayah kerja puskesmas Rasimah Ahmad Kota Bukit Tinggi, didapatkan hasil yaitu adanya perbedaan yang bermakna (terjadi penurunan) antara rata-rata kadar gula darah sebelum dan sesudah latihan pada kelompok intervensi, Selain itu, terdapat juga 2 orang responden $(12,5 \%)$ yang mampu mencapai kadar gula darah dalam rentang normal. Rata-rata kadar gula darah sebelum latihan adalah 191,06 mg/dl dan rata-rata kadar gula darah setelah latihan adalah 168,56 $\mathrm{mg} / \mathrm{dl}$.

\section{Tabel 5}

Distribusi responden menurut GDS sebelum dan setelah intervensi senam dan tidak senam

\begin{tabular}{lcccc}
\hline Gula darah & Mean & SD & P-value & N \\
\cline { 1 - 3 } Sebelum & 256,25 & 94,128 & 0,000 & 68 \\
\cline { 1 - 3 } \cline { 1 - 2 } Setelah & 235,37 & 77,697 & & 68 \\
\hline
\end{tabular}

Rata-rata guladarah sewaktu responden sebelum intervensi senam dan bukan senam adalah 256,25 dengan standar deviasi 94,128, sedangkan rata-rata guladarah sewaktu setelah intervensi senam dan bukan senam adalah 235,37 dengan standar deviasi 77,697. Hasil uji statistik diperoleh nilai $\mathrm{p}=$ 0.000 berarti pada alpha $5 \%$ ada perbedaan yang signifikan rata-rata guladarah sewaktu antara sebelum dan setelah intervensi senam dan bukan senam.

Prevalensi diabetes mellitus mencapai 24 kali lipat terjadi pada individu yang kurang aktif dibandingkan dengan individu yang aktif. Semakin kurang aktifitas fisik, maka semakin mudah seseorang terkena diabetes. Olahraga atau aktifitas fisik dapat membantu mengontrol berat badan. Selain itu, aktifitas fisik yang teraturjuga dapat melancarkan peredaran darah, dan menurunkan faktor risiko terjadinya diabetes mellitus. 
Dalam pengelolaan diabetes mellitus menurut Santoso dalam Suryanto (2009) ada 4 macam yaitu edukasi, perencanaan makanan, olahraga, dan Obat-obatan DM (OHO, Insulin), olahraga teratur untuk program pengobatan DM, terutama tipe II sudah dikenal sejak lama selain diet dan obatobatan. Senam atau olahraga bagi penderita diabetes manfaatnya akan lebih efektif bila jenis olahraga yang dilakukan mayoritas menggunakan otot-otot besar tubuh, dengan gerakan-gerakan ritmis (berirama) dan berkesinambungan (kontinyu) dalam waktu yang lama, (Suryanto,2009).

\section{SIMPULAN}

Berdasarkan hasil penelitian maka dapat disimpulkan bahwa:

1. Distribusi frekuensi responden yang melakukan olahraga senam diabetes, dari 68 responden yang diteliti, terdapat 34 responden melakukan senam diabet dan 34 responden tidak melakukan senam diabetes, namun pada kedua kelompok ini type DM, faktor umur, lama menderita, melaksanakan diet, dan aktifitas responden tidak homogen.

2. Perbedaan kadar gula darah sebelum dan sesudah olahraga senam diabetes, hasil uji statistik, diperoeh $\mathrm{p}=0.000$ berarti pada alpha $5 \%$ ada perbedaan yang signifikan rata-rata guladarah sewaktu antara sebelum dan setelah intervensi
3. Perbedaan kadar gula darah pada kelompok yang senam diabetes dan kelompok yang olahraga bukan senam diabetes, hasil uji statistik diperoleh nilai $\mathrm{p}$ $=0.000$ berarti pada alpha 5\% ada perbedaan yang signifikan rata-rata guladarah sewaktu antara sebelum dan setelah intervensi senam dan bukan senam

\section{UCAPAN TERIMA KASIH}

Ucapan terima kasih kepada Kepala dan Pegawai Puskesmas Periuk Jaya, Ketua Jurusan, Ketua Program Studi Poltekkes Kemenkes Banten, Kader, dan responden semua dan mahasiswa yang telah membantu penelitian ini.

\section{DAFTAR RUJUKAN}

1. Dinkes Kota Tangerang, (2016), Profil Kesehatan Kota Tangerang.

2. Corwin, Elizabeth J, 2009. Buku Saku Patofisiologi. Jakarta: Penerbit Buku Kedokteran EGC

3. Fox, Charles, Anne Kilvert. 2010. Bersahabat Dengan Diabetes Tipe 2. Jakarta: Penebar Plus https://books.google.co.id/books diakses pada tanggal 14 Maret 2017

4. Prince, Silvia A, Lorraine M. Wilson. 2006. Patofisiologi Konsep Klinis ProsesProses Penyakit. Jakarta: Penerbit Buku Kedokteran EGC

5. PUSDATIN Kemenkes RI. 2014. Situasi Dan Analisis Diabetes. Jakarta. pdf diakses pada tanggal 13 Februari 2017. 
6. Riskesdas. 2013. Prevalensi Diabetes, Hipertiroid \& Hipertensi

7. Setiadi. 2008. Konsep dan Proses Keperawatan Keluarga. Yogyakarta: Graha Ilmu

8. Soegondo, Sidartawan, dkk. 2009. Penatalaksanaan Diabetes Melitus Terpadu. Jakarta: Balai Penerbit FKUI

9. Sudoyo, Aru W. dkk. 2006. Buku Ajar Ilmu Penyakit Dalam Jilid 3 edisi 4. Jakarta: Balai penerbit FKUI

10. Suryanto.2009. Penerapan Olahraga Sanam Diabetes Indonesia Bagi Penderita Diabetes Mellitus. Medikora. pdf diakses pada tanggal 22 Februari 2017

11. Yendi dan Adwiyana. 2014. Pengaruh Latihan Jasmani Senam Diabetes Melitus Terhadap Penurunan Kadar Gula Darah Penderita Diabetes Melitus Di Wilayah Kerja Puskesmas Rasimah Ahmad Kota Bukit Tinggi http://ejournal.stikesyarsi.ac.id Diakses pada tanggal 14 Februari 2017. 